DE DE GRUYTER OPEN
Journal of Intercultural Management

Vol. 6, No. 4, December 2014, pp. 133-145

\author{
Ana María Larrañaga Núñez* \\ University of the West in Sinaloa, Mexico \\ José Octavio Molina Germán* \\ University of the West in Sinaloa, Mexico \\ Anel Yadira Pérez Melo* \\ University of the West in Sinaloa, Mexico
}

\title{
Perception of human capital competences for the provision of tourist services: an overview of visitors to the destination Mazatlan, Sinaloa, Mexico
}

\begin{abstract}
The consolidated tourist destinations are facing a stagnation situation, preamble to decline, stay, or rejuvenate (Butler, 1980). This perspective raises the need to develop strategies at national, local and organizational levels to maintain or increase the influx, spending and tourist permanence that generates greater benefits to the destination, which implies, necessarily, having human capital possessing ability, as well as the technical and behavioral competencies sufficient to cater to these visitors.

The purpose of the study is to analyze the perception of tourists regarding the competences of the human capital in lodging, food and transportation organizations in the city of Mazatlan Sinaloa. The research was conducted using a mixed methodology, being a descriptive, cross-sectional study. A questionnaire was used to develop the field work.

The human capital in the tourism sector that operates in the services of accommodation, meals and transportation in the destination of Mazatlan, has enough power from the perception of the visitors. The contribution of this research is considered relevant due to regularly surveyed tourists to learn about the satisfaction of service or from the perception of our human resources, which inferred the search for references about the state of the issue being addressed.
\end{abstract}

Key words: Perception visitors, human capital, competence, Mazatlan tourist destination

*anamaln@yahoo.com.mx; octavio.molina@udo.mx; anel.perez@udo.mx 


\section{Introduction}

The consolidated tourist destinations face a stagnation situation, the preamble to decline, remain in, or rejuvenate (Butler, 1980). In this perspective, there is a need to develop strategies at national, local and organizational levels to maintain or increase the flow, tourist spending and generate higher profits at the destination, which implies, to have human capital possessing the capacity and sufficient technical and behavioral competencies to meet these visitors.

Acosta, and Mollón Fernández (2002) indicate that in the tourism sector, in particular, hotels, a weakness is manifested in the proper training of employees who sometimes assume the activities under the precepts of improvisation, so that it does not meet the expectations of increasingly demanding tourists.

By contextualizing tourism in Mexico based on the economic theories of labor markets, Mendez Rodriguez Osorio and Salgado (2013) allude to changes on the labor market, noting that while in the past, employment in tourism was cataloged as flexible and precarious, currently the globalizing neoliberal stage take it to the extreme in a model that requires greater technical staff, with medium and high training skills.

Offering services with high quality standards represents an ongoing challenge for those within the tourism industry. Achieving the above is a complex task that has many edges. Hence the importance of analyzing the skills that shows employees in the lodging, food and transportation organizations in the destination of Mazatlan, Sinaloa, Mexico.

This city is the second largest in the state of Sinaloa, Mexico. Its main economic activity is tourism, with 69,450 jobs in the hospitality, commercial, restaurateur, and transportation sector as well as cultural and recreational services (City of Mazatlan, 2011). The statistical compendium of tourism in Mexico 2013, the Ministry of Tourism, says that tourist arrivals was $1,743,575$, corresponding to $81.1 \%$ nationally, mainly from Distrito Federal, Coahuila and Chihuahua and 18.9\% internationally, especially from the United States and Canada. The average stay is 2.73 tourists per night.

\section{Human Capital and competence in tourism}

Becker (1983) and Bardarova et al, mentioned that human capital is a set of production skills, talent and knowledge of people, acquired by education, scientific research, job training and experience. Davenport (1999) refers to the human capital as the capacity, behavior, effort and time employees spend at work. The ability, knowledge and talent; behavioral values such as ethics, beliefs and reactions to the world are expressed in the capacity or expertise of the activity. The effort is a conscious application of mental and physical resources for a particular purpose; while time is a chronological human capital investment. 
In the evolution of the concept of human capital, Morales (2005) following Schultz (1959) mentions that human resources have quantitative and qualitative dimensions: the first one has the number of people, the percentage of the active population, and the number of hours worked. In the latter is considered for operational skills, knowledge and similar attributes that affect an individual's ability to perform productive work.

Generically, competence is defined as a set of abilities, skills, knowledge and attitudes that are specified assertively in problem solving or in a relevant response to a new or specific situation according to the National System of Competence in Mexico (Consejo de Normalización y Certificación de Competencia Laboral,, CONOCER, 2014).

The International Labour Organization, ILO (2000), in relation to education and training in tourism indicates that the complexity of the workplace requires training, with an evolution of operational to personal skills towards professional and social skills. The new competences should allow workers to reach the necessary autonomy at work: the ability to learn and develop activities to assimilate all the elements of a complex process, and real communication skills, including negotiation in case of conflict.

Therefore, competences of the human capital in tourism are understood as the knowledge, skills and values that are found in operative employees, managers and executives to provide an efficient service that meets the expectations of the visitors in a destination.

At CONOCER, in relation to tourism, there are standards of the following skills: 1. Attention to diners, 2. Coordination of food and beverage services, 3. Coordination of housekeeping services and areas of stay for temporary housing, 4 . Hygienic food handling, 5. Cleaning industrial kitchens, 6. Operation of pools, 7. Food preparation, 8. Preparation of rooms for temporary housing, 9. Preparation and beverage service, 10. Providing reception and guest service for temporary accommodation, 11. Provision of customer service, and 12. Monitoring the conditions of registration and guest's stay.

The competence of human capital in this research is studied from the perception of tourists, who temporarily move from one place to another to satisfy their need for entertainment, which for a time; they stay outside their usual place of residence (Ascanio, 2012).

Therefore, the purpose of the study is to analyze the perception of tourists about the competences of human capital in lodging, food and transportation organizations in the city of Mazatlan, Sinaloa. The hypothesis is that human capital that provides lodging, food and transportation in the touristic destination of Mazatlan, has sufficient competences from the perception of the tourist. 


\section{Methodology}

The research methodology applied is a mixed approach, with a descriptive, cross-sectional study. To develop fieldwork a questionnaire, subjected to expert validation, was applied. The sample used was of 117 respondents.

The questionnaire contains two sections. The first refers to the socio-demographic data, the visitor was asked: place of origin, sex, age, frequency of visiting Mazatlan, level of education and transportation used.

The second section contains the set of items that identifies the visitors' perception concerning the skills of employees that offer services related to accommodation, food and transportation. The questionnaire statements emphasize the knowledge, attitudes and values shown in the technical standards and / or standardization of labor competence of the CONOCER, in questions 1 to 14 and 17-18. Questions 15 and 16 refer to competences of provision of customer service, but employees (drivers, local transportation and foreign tourism support) do not appear defined in the above mentioned standards.

Criteria apply to people aged 16 and older which had stayed in accommodation establishments, who were surveyed in site, in areas such as the boardwalk, beaches and squares, considered the major areas of tourists in Mazatlan.

\section{Empirical results}

The information resulting from this study is presented in two sections: the first results of the socio-demographic data of visitors and in the second, the perception of the competence of employees in each analyzed dimension.

Socio-demographic data of the informants:

Table 1 Sex, age, occupation and transporting visitors

\begin{tabular}{|c|c|c|c|c|c|}
\hline Sex & Number & Percentage & Occupation & Number & Percentage \\
\hline Female & 69 & 59.0 & Student & 32 & 27.4 \\
\hline Male & 48 & 41.0 & Businessman & 17 & 14.5 \\
\hline & & & Housewife & 12 & 10.3 \\
\hline Age & Number & Percentage & Employee & 37 & 31.6 \\
\hline $16-29$ & 58 & 49.6 & Other & 19 & 16.2 \\
\hline $30-44$ & 43 & 36.8 & & & \\
\hline $45-64$ & 12 & 10.3 & Transport & Number & Percentage \\
\hline 65 or more & 4 & 3.4 & Air & 14 & 12.0 \\
\hline & & & Bus & 60 & 51.3 \\
\hline
\end{tabular}




\begin{tabular}{|c|c|c|c|c|}
\hline & Private car & 43 & 36.8 \\
\hline Total & \multicolumn{2}{|c|}{117} & \multicolumn{2}{|c|}{100.0} \\
\hline
\end{tabular}

Source: Own elaboration, 2014

The highest percentages in the number of respondents, Table 1 correspond to females with $59.0 \%$, the segment of ages 16 to 29 years with $49.6 \%$; in employment to employees with $31.6 \%$. The shuttle bus arrival corresponds to $51.3 \%$. While the lowest percentage corresponding to age 65 years, $3.4 \%$ in love occupancy houses, $10.3 \%$ and air transport with $12.0 \%$.

Figure 1 Origin of visitors

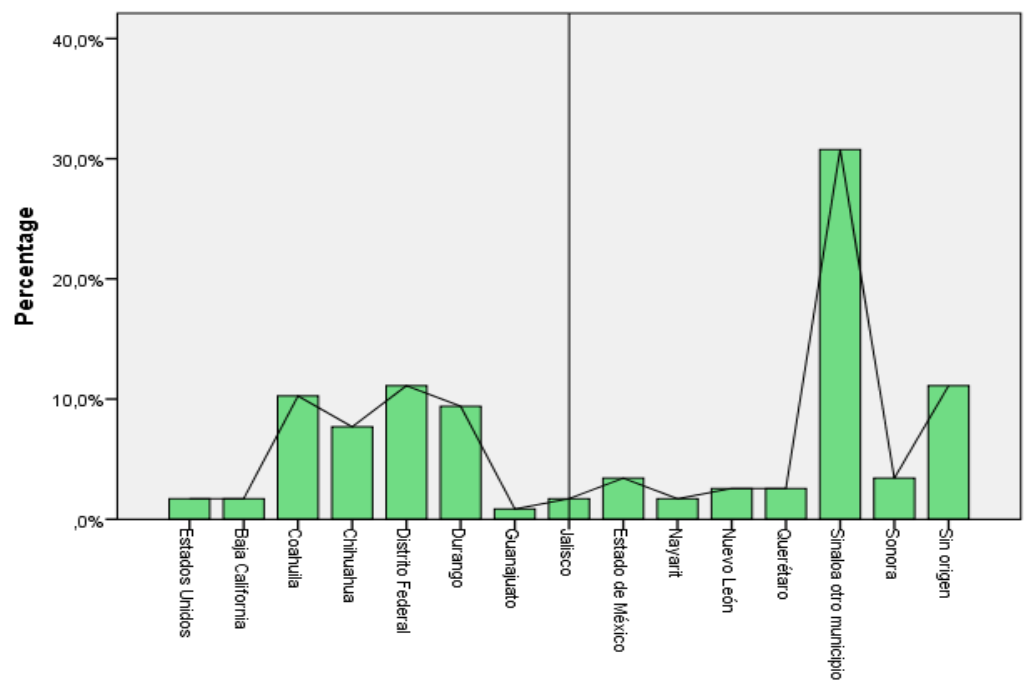

The origin of the visitors according to Figure 1 shows that, from 15 destinations inside Mexico and one country other than Mexico, the United States. Visitors are about 30\% from Sinaloa (other municipalities), 11\% from Distrito Federal, 10\% from Coahuila and 9\% from Durango; in smaller percentages you have Aguascalientes, Guanajuato and the United States. 
Table 2 Frequency of visits to Mazatlan tourist destination

\begin{tabular}{|c|c|c|}
\hline \multirow{2}{*}{ Concept frequency } & \multicolumn{2}{|c|}{ Frequency } \\
\cline { 2 - 3 } & Absolutes & Percentage \\
\hline First time & 28 & 23.9 \\
Every month & 10 & 8.5 \\
Every three months & 12 & 10.3 \\
Every six months & 20 & 17.1 \\
Every year or more & 47 & 40.2 \\
Total & 117 & 100.0 \\
\hline
\end{tabular}

Source: Own elaboration, 2014

$40.2 \%$ of informants indicated that they visit Mazatlan every year and $23.9 \%$ for the first time, to a lesser extent you have every month visitors to an $8.5 \%$ as shown in Table 2.

Visitor perception regarding competence in basic services (accommodation, food and transportation)

The average perceived competence of human capital is valued as good with a $52.7 \%$ in the three basic services that are studied, while there is a tiny negative or bad rating of $0.2 \%$. It is observed that only transportation is rated very good with $50.2 \%$ and the rest appears below $40.0 \%$, Table 3 .

Table 3 Perceived competence of human capital in accommodation, food and transportation

\begin{tabular}{|c|c|c|c|c|c|}
\hline $\begin{array}{c}\text { Perception of } \\
\text { competence }\end{array}$ & Accommodation & Food & Transportation & $\begin{array}{c}\text { Responsible } \\
\text { human capi- } \\
\text { tal }\end{array}$ & Average \\
\hline Very bad & 0.2 & 0.4 & 0.3 & & 0.2 \\
Bad & 2.1 & 1.4 & 0.6 & & 1.0 \\
Fair & 5.8 & 8.3 & 2.3 & 2.5 & 4.7 \\
Good & 52.2 & 53.0 & 46.6 & 59.0 & 52.7 \\
Very good & 39.7 & 36.9 & 50.2 & 38.5 & 41.4 \\
& 100 & 100.0 & 100.0 & 100.00 & 100.00 \\
\hline
\end{tabular}

Source: Own elaboration, 2014

Notes: In the different transportations, the total was considered without missing values It includes separate Responsible Human capital, as it was questions covering all three services. 
Figure 2 Cleanliness of the room

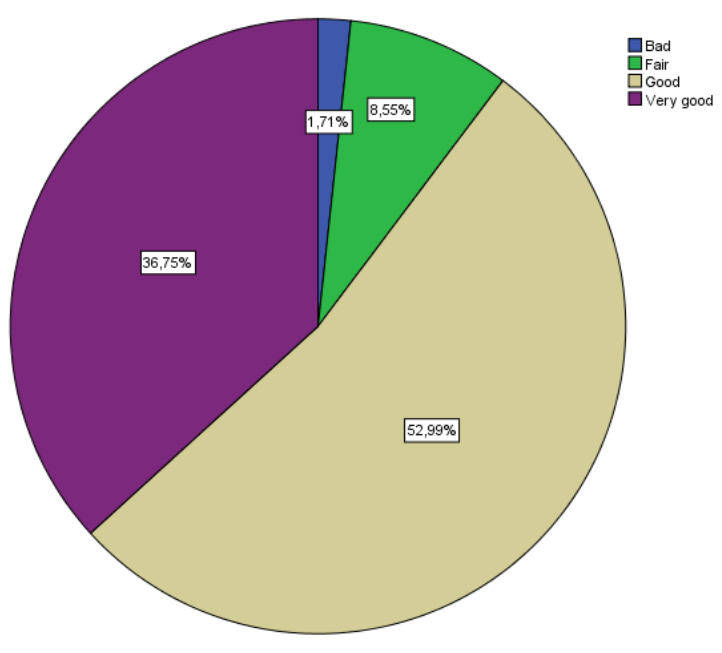

Source: Own elaboration, 2014

In the standardization of competence, coordination of housekeeping services and areas of stay for temporary housing and preparing rooms for temporary housing, the human resources of the clean room presentation (Maids, rooms division manager, etc.) are incorporated. In figure $2,52.9 \%$ of the visitors consider good the competence of maids while $8.5 \%$ considered it between fair and bad.

Figure 3 Communication from the receptionist

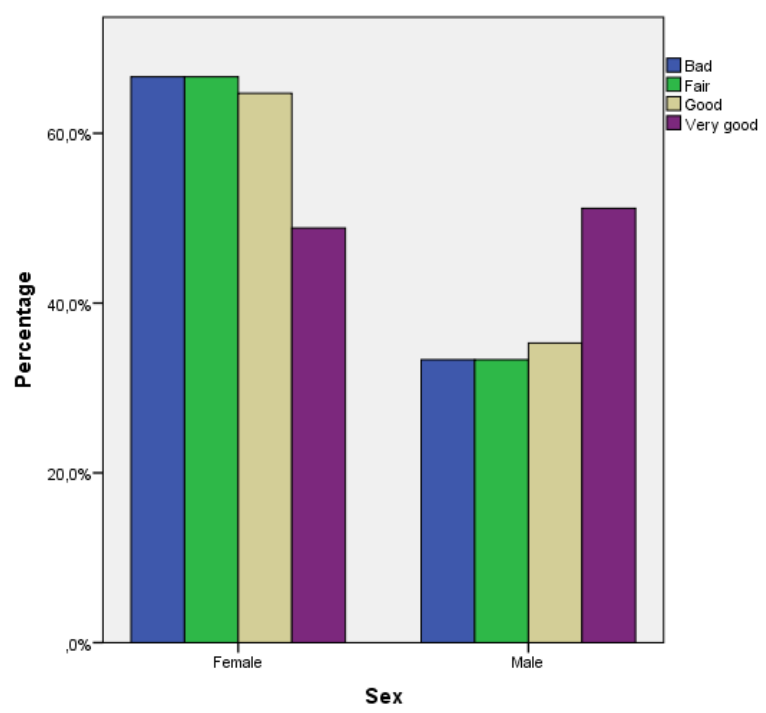

Source: Own elaboration, 2014 
The standard of competence providing reception and guest services for temporary accommodation, provision of customer care and supervision of the conditions of registration and residence of the host, is referred to human resources (receptionist, reception and accommodation managers). The perception of tourists regarding to information and communication of the receptionist had the highest percentage of good with $57.0 \%$, while the percentage of bad and fair approach $7 \%$. This variable is divided by sex, being woman answering good in a $67.0 \%$, and $65.0 \%$ fair. $51.2 \%$ men said very good and $35.3 \%$ good, figure 3 .

Moreover, the standard of competence providing of customer care and supervision of the conditions of registration and guest stay where they are managers accommodation, hotel administrator, hotel managers and front desk receptionist and telephone operators, they are related to the concept of problem in the hotel. $75.21 \%$ of the visitors said to have no problem at the hotel and $24.79 \%$ said yes. While the answers to solve problems, $72.0 \%$ mentioned having good experiences and $10.0 \%$ said bad experiences, figure 4 .

\section{Figure 4 Solving problems in the hotel}

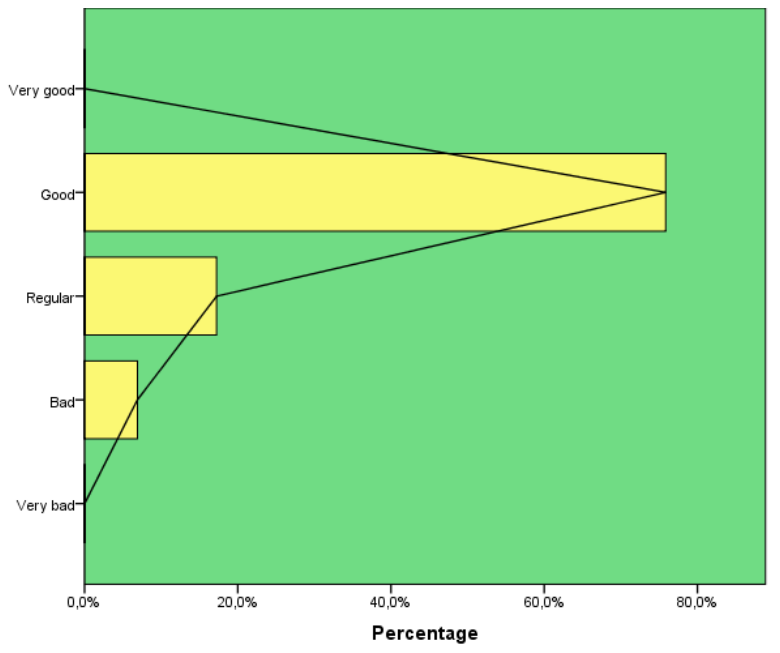

Source: Own elaboration, 2014

Regarding the competence standard of room preparation for temporary housing, services for customers and, service reception and guest services for temporary accommodation, incorporate a friendly attitude. The visitors replied that hotel staff demonstrate very good friendliness by $55.56 \%$ and $0.85 \%$ indicated a very bad kindness.

The perception of the friendliness of the hotel employee, according to the occupation of the visitor, Table 4 , realizes that employee informants reported the highest 
percentage with $24.6 \%$ of a very good kindness and good with $41.7 \%$; while $66.7 \%$ students perceived it as fair kindness, as well as perceiving a very bad kindness in tiny proportions.

Table 4 Perceptions friendly hotel employee according to the occupation of the visitor

\begin{tabular}{|c|c|c|c|c|c|c|}
\hline \multirow{2}{*}{\multicolumn{2}{|c|}{ Occupation visitor }} & \multicolumn{4}{|c|}{ Perception of kindness } & \multirow{2}{*}{ Total } \\
\hline & & \multirow{2}{*}{$\frac{\text { Very bad }}{1}$} & \multirow{2}{*}{\begin{tabular}{r|} 
Fair \\
\end{tabular}} & \multirow{2}{*}{$\frac{\text { Good }}{15}$} & \multirow{2}{*}{$\frac{\text { Very good }}{14}$} & \\
\hline Student & No. & & & & & 32 \\
\hline & $\%$ & 100.0 & 66.7 & 31.3 & 21.5 & 27.4 \\
\hline \multirow[t]{2}{*}{ Businessman } & No. & 0 & 0 & 5 & 12 & 17 \\
\hline & $\%$ & 0.0 & 0.0 & 10.4 & 18.5 & 14.5 \\
\hline \multirow[t]{2}{*}{ Housewife } & No. & 0 & 0 & 4 & 8 & 12 \\
\hline & $\%$ & 0.0 & 0,0 & 8,3 & 12.3 & 10.3 \\
\hline \multirow[t]{2}{*}{ Employee } & No. & 0 & 1 & 20 & 16 & 37 \\
\hline & $\%$ & 0.0 & 33.3 & 41.7 & 24.6 & 31.6 \\
\hline \multirow[t]{4}{*}{ Other } & No. & 0 & 0 & 4 & 15 & 19 \\
\hline & $\%$ & 0.0 & 0.0 & 8.3 & 23.1 & 16.2 \\
\hline & No. & 1 & 3 & 48 & 65 & 117 \\
\hline & $\%$ & 100.0 & 100.0 & 100.0 & 100.0 & 100.0 \\
\hline
\end{tabular}

Source: Own elaboration, 2014

In relation to the standard of care competencies diners, food preparation, food hygiene management, coordination of food and beverage services, including cooks, food service assistants and beverages, bakers, majority of kitchen helper cook, bartender, restaurant captain, engineers in food processing, specialized technical food and beverages, etc., the question relates to food presentation according to the expectations of the visitors. $48.0 \%$ said good, Figure 5 , while $43 \%$ said very good and 9\% fair to very bad.

The standard of competence coordination of food and beverage service, attention to diners, is where waiters and technicians specialized in food and beverages are included to the questions of problems in the restaurant. $85.47 \%$ said not having problems, while $14.53 \%$ did have. The direct relationship of this question to the solution of problems in the restaurant, Figure 6, is said 58\% responded good, $36 \%$ had a fair solution, $5 \%$ in a bad solution. 
Figure 5 Presentation of food in accordance with expectations

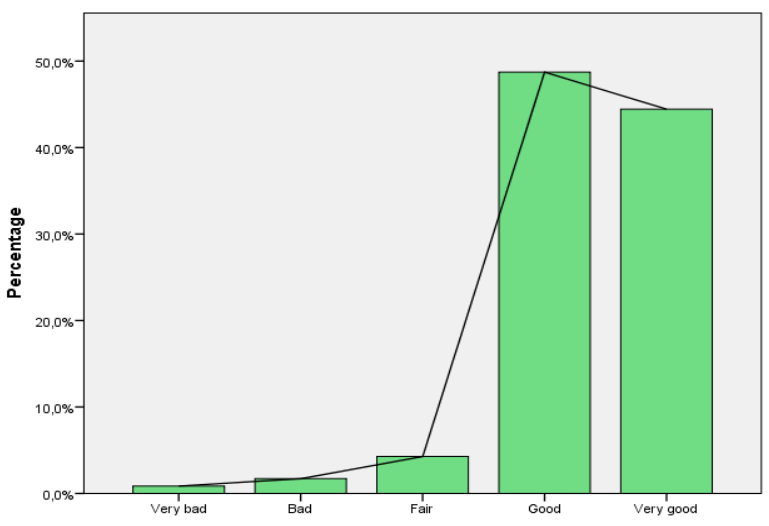

Source: Own elaboration, 2014

Figure 6 Solving problems restaurant

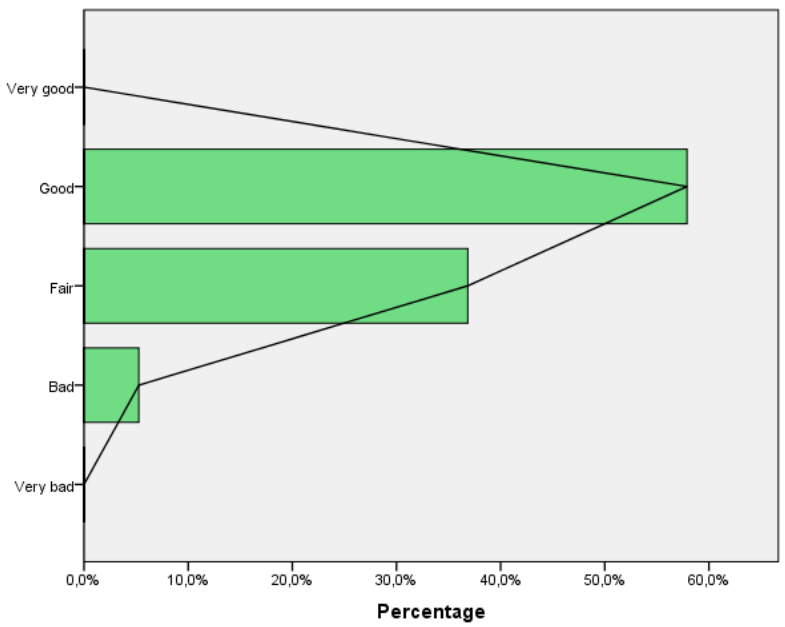

Source: Own elaboration, 2014

Attitude-value of responsibility appears not to provide reception and guest services for temporary accommodation, preparation and serving of beverages and operation pools in $75 \%$ of the standards of competence. The ask visitor was conducted on a general assessment of the three services: accommodation, food and transporta- 
tion and answers, figure 7, realize that $59.0 \%$ perceived good, $38.5 \%$ very good and $25 \%$ fair.

Figure 7 Responsibility for employees

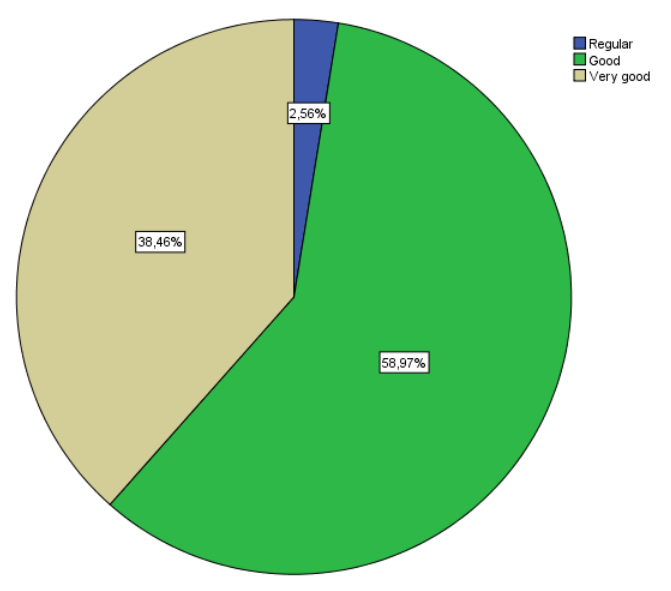

Source: Own elaboration, 2014

In the standard of competence for the development of tourism activities, was found to transport personnel. It was decided to ask the question for perception in the attention of local transportation personnel as part of the basic service offered to visitors. Responses of visitors, figure 8, realize that $55.0 \%$ reported that accountability is good and $45.0 \%$ very good, $4 \%$ said poor to very bad.

Figure 8 Attention local transport staff

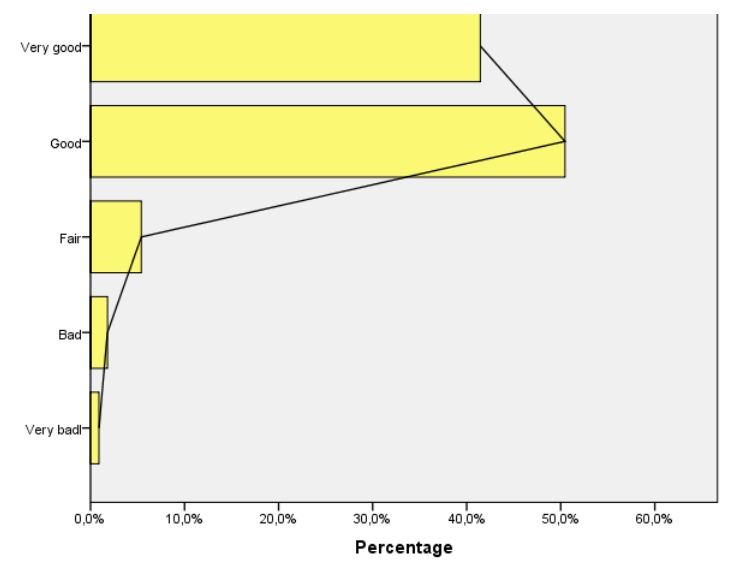


With regard to the question of what aspects would recommend for training employees responses were in absolute numbers were: customer service is 50; All is well, 41 and in communication, 5. fewer were: problem solving, planning influx, personality, knowledge of tourism, health, first aid.

In regard to the questions of attitudes, I would advise employees to improve their performance based in the replies received, in absolute numbers: 21 in kindness; 11 in dynamism and 7 adequate expressions. With a lower number availability, initiative, spirit of service, cleanliness, empathy.

\section{Conclusion}

Human capital in the tourism sector operates in the accommodation, food and transportation services in the destination of Mazatlan, has sufficient competence in the perception of visitors, considering the average value of $52.7 \%$ as good which added to very good $41.4 \%$, totaling $94.1 \%$ which is interpreted as a positive perception.

Regarding the variable frequency of visit to Mazatlan, opportunities are inferred as $23.9 \%$ of respondents mentioned that for the first time and $40.2 \%$ each year. This means that with an improvement in education and training strategies of human capital competence, it would help in maintaining, and eventually increase the number visitors.

The areas of opportunity to improve human capital competence in food and accommodation service focus on problem solving, which proves that there is a demand for a consumer with evolving behaviors and values (ILO, 2000).

The strength is the attitude responsibility of employees in the three areas addressed in the questionnaire averaged 59.0 good and 38.0 very good from the perception of the visitor, so its use is recommended in the sector.

Finally, the contribution of this research is considered relevant because tourists are surveyed regularly to learn about service satisfaction or from the perception of human resource itself, which was inferred from the reference search on the state the issue addressed.

\section{References}

Acosta, A. J., Fernández, N., Mollón, M. (2002). Recursos humanos en empresas de turismo y hostelería, España, Editorial Prentice Hall.

Ascanio Guevara, A. (2012). Teoría del turismo, México, Editorial Trillas.

Ayuntamiento de Mazatlán (2011). Plan municipal de desarrollo 2011-2013. Recuperado de www.mazatlan.gob.mx

Becker, G. (1983). El Capital Humano, España, Editorial Alianza,

Butler, R.W. (1980). «The Concept of a Tourist Area Cycle of Evolution: Implications for Management of Resources», en Canadian Geographer, Western Ontario University, XXXIV (1), pp. 5-12. 
Davenport, T.O. (1999). Capital humano, creando ventajas competitivas a través de las personas, España, Editorial Gestión 2000, S.A.

Méndez, M.C. Rodríguez, O. M., Osorio, M. y Salgado, M. C., (2013). La flexibilidad laboral en el sector turístico en México. Una interpretación teórica, Revista Estudios y perspectivas del turismo, 22 (4), pp, 705-728, disponible en http://www.redalyc.org/articulo. oa?id=180728712005

Morales, R. (2005). En torno al capital humano, aspectos básicos en su consideración empresarial, España, Editorial Centro de Estudios Ramón Areces, S.A.

Organización Internacional del Trabajo (2000). El desarrollo de los recursos humanos, el empleo y la mundialización en el sector de la hotelería, la restauración y el turismo, Ginebra, Recuperado de http://observatoriodelacapacitacion.stps.gob.mx/oc/pdf/9_desarrollo_recursos_humanos_empleo_mundializacion.pdf

Ruiz, M. V., Ramírez, J. J. y Pérez, J. (2012). El capital humano en las Micro y Pequeñas Empresas Turísticas de la ciudad de Texcoco, Estado de México Revista El Periplo Sustentable, No. 22, pp. 145-162, disponible en http://www.redalyc.org/articulo.oa?id=193424438006

Secretaría de Turismo, Estadística DATATUR, Compendio estadístico del turismo en México 2013. Recuperado de http://datatur.sectur.gob.mx/wb/datatur/publicaciones

Sistema Nacional de Competencias, CONOCER. Registro nacional de estándares de competencia, Estándares de competencia y certificación de competencias de las personas. México. Recuperado de http://www.conocer.gob.mx/index.php/estandaresdecompetencia

Villalobos, M. (2009). Evaluación del aprendizaje basado en competencias. México, D. F.: Editorial Minos Tercer Milenio. 